\title{
Uncovering the origin of ambiguity in nature-inclusive flood infrastructure projects
}

\author{
Ronald E. van den Hoek ${ }^{1}$, Marcela Brugnach ${ }^{1}$, Jan P. M. Mulder ${ }^{1,2}$ and Arjen Y. Hoekstra $^{1}$
}

\begin{abstract}
We aimed to uncover the origin of ambiguity in flood infrastructure projects using Building with Nature (BwN) design principles. BwN is a new approach in flood management that simultaneously integrates societal goals, such as flood safety and recreation development, with nature development goals by actively using natural dynamics and materials in the project's design. Because BwN projects affect multiple stakeholders and several societal functions, participatory project development is of key importance to successfully implement these projects. In such a multiactor decision-making process, a diversity of actors are involved, all of whom have their own view of the project based on their interests, values, beliefs, backgrounds, and past experiences. As a consequence, BwN projects are susceptible to being hampered by the presence of ambiguity, a kind of uncertainty that results from the simultaneous presence of multiple frames. For two BwN case study projects, we identified where the ambiguities potentially affecting project development resided, derived the different actor frames, and addressed the attributes underlying these frames. Our main finding was that ambiguity in BwN projects seems to originate from a contradiction between the beliefs held by different actors. Furthermore, our results suggest that in the current practice of $\mathrm{BwN}$ projects the scientific knowledge of experts is perceived as more legitimate than the local knowledge and experiences of lay actors, which implies that experts have a more powerful position in multiactor decision making. Thus, our research underlines the difficulty of bringing local knowledge and past experiences of lay actors into collective decision making.
\end{abstract}

Key Words: ambiguity; Building with Nature; flood management; framing; participatory processes; water policy

\section{INTRODUCTION}

Water systems have always challenged human communities because the threat of flooding has never been far from society's doorstep. In the 20th century, flood infrastructure was dominated by rigid structures such as dikes, dams, and storm surge barriers, which are intended to strictly regulate and control water systems. Although the application of rigid structures to prevent flooding has been a success in the recent past, the negative impact of such strategies on ecosystems and natural processes is often not properly taken into account in flood management (Richter et al. 2003). Over the years, there has been a growing emphasis on incorporating ecological values in water policy (Gleick 2000). This is reflected in water management, where the paradigm is slowly changing toward more nature-inclusive approaches (Pahl-Wostl et al. 2011). Building with Nature $(\mathrm{BwN})$ is a new approach of nature-inclusive flood management in the Netherlands. Instead of using the described rigid structures, which intend to strictly regulate and control water systems, BwN design principles aim to utilize natural dynamics, e.g., wind and currents, and natural materials, e.g., sediment and vegetation, for the realization of effective flood infrastructure while providing opportunities for nature development (De Vriend and Van Koningsveld 2012). Because projects using $\mathrm{BwN}$ design principles simultaneously integrate societal goals such as flood safety and recreation with nature development goals, multiple actors with a diversity of backgrounds are either directly involved or affected. Thus, to establish successful initiatives and come up with solutions that are acceptable for all those actors, participatory project development is of key importance.

In participatory project developments, such as those proposed by $\mathrm{BwN}$, decisions are made collectively, favoring the involvement of a diversity of actors from different sectors and levels, i.e., state, regional, and municipal. The underlying rationale is that including a diverse range of actors can lead to a more integral and better accepted project development process (Bouwen and Taillieu 2004, Pahl-Wostl et al. 2007a). However, despite its benefits, multiactor decision-making processes can be complicated to reach and implement. One difficulty originates from the multiplicity of frames that may be simultaneously present in decision making. In a multiactor setting, each actor can frame the project differently, causing a situation of ambiguity in which it is no longer clear what the issues of concern and action paths are (Brugnach et al. 2011), hindering participation and collaboration among actors. This consideration suggests that paying attention to ambiguity and framing differences is of essential importance in nature-inclusive flood infrastructure projects. This idea is also supported by previous research on the Sand Engine project, an innovative sand nourishment project based on BwN design principles, which showed that the Sand Engine's project development process was susceptible to being hampered by ambiguity (Van den Hoek et al. 2012).

However, dealing with differences in framing is far from straightforward because the resulting ambiguity can polarize the actors. Although some ambiguity is a necessity for generating change and innovation, it has to be kept at a manageable level (Dewulf et al. 2005) because framing differences can also result in intergroup conflict (Gray 2004). This issue is illustrated by the Sand Engine project, where opponents of the initiative had a negative view of the project's effects on swimming safety and demanded its cancellation. Because the project team was not willing to fulfill this request, the conflict even ended up in the Dutch parliament: A large political party supported the opponents, posed critical questions, and demanded the immediate cancellation of the initiative (Van den Hoek et al. 2012). Although the project was eventually implemented successfully, this incident clearly illustrates the importance that ambiguity can have in the 
development of flood infrastructure projects using BwN principles. Moreover, it points to the need to identify the origin of the underlying framing differences to develop better strategies for dealing with ambiguity and thereby prevent unnecessary cost overruns, delays, or cancellation of promising initiatives.

The goal of this research is to investigate the origin of ambiguity in flood infrastructure projects using $\mathrm{BwN}$ design principles. To this end, we studied the framing differences that emerged between the project development team and the stakeholders in two different BwN projects, namely the Sand Engine Delfland and the Safety Buffer Oyster Dam. Our analysis focused on identifying the differences that existed between the frames held by individual actors during project development. We paid particular attention to conflicting stakeholder interests, diverging values and beliefs, different backgrounds, and past experiences as triggers of framing differences that may lead to ambiguity. For both aforementioned case studies, we performed interviews with key project actors, attended public project meetings, and studied project documents as supporting material. After the data collection, we identified which ambiguities were most important for the case study project's development process, characterized the individual actors' frames regarding these ambiguities, and identified the actor attributes underlying these frames.

\section{FRAMES, FRAMING, AND AMBIGUITY IN DECISION MAKING}

A frame refers to a sense-making device that mediates the interpretation of reality (Weick 1995). As such, it indicates what is relevant for an actor, or a group of actors, regarding a decision issue or an event. Through framing, a decision issue or an event acquires meaning, drawing the limits of what the problem is that needs to be decided on, how it is defined, and who is part of the decision making (see Schön and Rein 1994, Benford and Snow 2000, Dewulf et al. 2009 for reviews on frames and framing processes). Actors' frames may diverge from one another, so in a decision-making process with multiple actors involved, the simultaneous presence of different but equally valid frames is unavoidable. When these frames are incompatible, they can cause a specific type of uncertainty called ambiguity, which indicates that there are different possible, yet equally valid, interpretations of a problem situation (Brugnach et al. 2008, 2011).

As illustrated in the Introduction, a situation of ambiguity can be a major problem in decision making because it can easily result in a state of indecisiveness or even conflict. The relevant dimension of ambiguity is something ranging from unanimous clarity to total confusion caused by too many people voicing different but still valid interpretations (Dewulf et al. 2005). Different facts can mean different things for different actors, different issues can be held as relevant facts, and different solutions can be favored (Schön and Rein 1994, Dewulf et al. 2004). Although similarities between actors and their preferences will probably contribute to avoid ambiguity, completely shared meaning and views are not required in multiactor decision making. Donnellon et al. (1986) argue that so-called equifinal meaning is sufficient: interpretations that are dissimilar but that have similar behavioral implications. If there is sufficiently shared understanding among actors, then they have a common ground to come to a collective action or decision.

\section{Actor attributes related to frames}

Dewulf and Bouwen (2012:170) elaborate on the topic of framing differences and define issue framing as "arranging and rearranging the elements of an issue such that its meaning is altered. [This is] a process which involves selecting certain issue elements as part of the frame while leaving out others and putting particular issue elements into focus while leaving only a marginal role for other elements." In short, this implies that individual frames can differ at a particular point in time when a focal element of the frame of one actor challenges or conflicts with a focal element of the frame of another actor with whom he or she interacts. For this research, we performed an extensive literature review to identify specific elements or attributes that several authors mention as playing an important role in framing processes and the formation of individual actors' frames.

Interests, i.e., the ambitions or goals of an actor and/or his or her organization, affect the framing process. Schön and Rein (1994) address that there is a reciprocal, but nondeterministic, relationship between an actor's frames and interests. Hence, although interests influence the way we frame an issue, frames can also influence our interests. In their studies on social movement organizations (SMOs), Snow et al. (1986) and Benford and Snow (2000) also discuss the connection between framing and interests; they argue that creating a shared interest is a proper strategy to align frames among the SMO's participants and potential new SMO members.

The values and beliefs of an actor influence how he or she frames an issue (Benford and Snow 2000, Nisbet and Mooney 2007, Brugnach and Ingram 2012). Values reflect an actor's sense of right and wrong and what he or she holds as important, whereas beliefs are propositions or premises an actor holds to be true. Hoekstra (2000) concludes that the perspectives actors hold in controversies in the field of water resources management differ because of their underlying basic values, beliefs, and assumptions. Dewulf et al. (2005) discuss that differing beliefs can inform very different ways to make sense of an issue and can thus lead to different frames. Renn et al. (2011) address the topic of ambiguity and state that it refers to the presence of multiple values.

Personal backgrounds and experiences shape the way we frame (Bouwen and Taillieu 2004, Gray 2004). Actors with a background in either the natural or the social sciences can frame an issue rather differently (Dewulf et al. 2005). Furthermore, highly personal experiences, which are part of a personal subjective history, can inform different ways of making sense of a situation (Weick 1995). Moreover, even if actors supposedly share the same experiences, they may still use different repertoires to make sense of what is going on (Brummans et al. 2008). Gamson and Modigliani (1989) and Nisbet (2009) discuss the role of the media in framing and state that to make sense of policy discussions, the audience integrates the frame provided by the media with its own pre-existing interpretations based on, for instance, personal experiences.

Frames can also derive from the societal position of an actor (Dewulf et al. 2005, Pahl-Wostl et al. 2007a, 2007b). In a multiactor decision-making process, an actor can yield power from his or her specific position by holding specific knowledge or from having a good reputation. Kaplan (2008) states that one frame can prevail over another if actors can gain power by 
supporting the frame of more powerful actors. De Boer et al. (2010) argue that actors with more power have more control over frames that are being used. Carragee and Roefs (2004) address that the role of power in framing is often neglected, whereas it is in fact a key issue. Furthermore, framing can be influenced by the political position of an actor. Framing differences can originate out of different levels of government because of differences in electorate scale and responsibility (Dewulf et al. 2005). As Brugnach et al. (2011) state, ambiguity can occur at different political levels, and preferences at the regional policy level may partly contradict local and/or national policies.

In short, the results of our literature review suggest that the way in which an actor frames an issue is influenced by that actor's interests, values, beliefs, background, previous experiences, and societal or political position. These attributes influence how people interpret reality and the type of interactions in which they engage. We focus on an analysis of how ambiguity in decision making originates from a difference between the frames of individual actors. Building on the previously discussed work of Dewulf and Bouwen (2012), we suggest that the individual actor attributes can be interpreted as issue elements, of which some may contribute to an actor's frame regarding a certain issue and others may not. If the actors involved in a multiactor decision-making process incorporate conflicting elements in their frames, the resulting framing difference can cause a tension potentially leading to a situation of ambiguity.

\section{METHODS}

As mentioned in the Introduction, we studied two flood infrastructure projects based on $\mathrm{BwN}$ design principles, namely the Sand Engine project and the Safety Buffer Oyster Dam project. We selected these specific projects because they are two of the most well-known examples of $\mathrm{BwN}$ projects in the Netherlands. Future BwN projects are likely to resemble these two initiatives. Additionally, we already had existing contacts with people involved in the projects.

For both case studies, we used interviews and observations as our main data collection methods. For the Sand Engine project (see Case Study 1: Sand Engine Delfland), we first attended three public information meetings. During these meetings, stakeholders, i.e., those affected by the project who are not part of the project team, and the general public had the opportunity to pose critical questions, express their appreciation or concerns about the project, and file complaints. Minutes of these meetings were made and studied to understand the viewpoints of the stakeholders. Second, in April and May 2011, we interviewed six actors associated with the project team, i.e., three former members of the Sand Engine project team, one member of the project steering group, and two experts involved in the environmental impact assessment (EIA) and modeling, about uncertainty during project development. The semistructured interviews were conducted in the Dutch language, took between one and two hours, and were recorded and transcribed. A standardized interview protocol with seven open-ended main questions and several follow-up questions was used. During the interviews, the interviewees were invited to elaborate on their definition or understanding of uncertainty. Thereafter, the interviews continued with an iterative process of identifying uncertainties and elaborating on the uncertainty's relevance for the Sand Engine development process. We specifically examined the ambiguities we identified in the project and did not take other types of uncertainty into account.

For the Safety Buffer Oyster Dam project (see Case Study 2: Safety Buffer Oyster Dam), first, we attended a meeting of the project's knowledge development team in March 2012. This meeting was recorded and transcribed. The various discourses between actors were analyzed to identify the project's main discussion topics and framing differences. Second, in April 2012, we attended a meeting of the project's sounding board, consisting of multiple stakeholders. During this meeting, the project team informed the sounding board on the progress of the project's development and invited them to respond to three alternative project designs. The meeting was not recorded, but minutes were made and studied to identify the main discussion topics and framing differences. Third, we conducted 4 interviews with actors associated with the project team, performed by 2 interviewers, and 9 interviews with stakeholders, performed by 1 interviewer, in July, August, and September 2012. During 3 of these interviews, 2 respondents were interviewed instead of 1 . Hence, in total, we spoke to 6 project team actors, i.e., 3 at the executive level and 3 at the project level, and 10 stakeholders. The semistructured interviews were conducted in the Dutch language, took about 1 hour, and were recorded and transcribed. Two standardized interview protocols, i.e., 1 for the project team actors and 1 for the stakeholders, with up to 14 open-ended main questions were used. During the interviews, the interviewees were invited to elaborate on those project topics that were most important for them, but that also caused the hardest discussions within the project because of the existence of diverging viewpoints.

For both cases, our analysis started with identifying which ambiguities were most important by considering two aspects: the ambiguity's potential impact and its project-wide relevance for the actors. During the interviews, we invited the interviewees to elaborate on the impact each ambiguity identified could have on the project's development process, e.g., whether this ambiguity could lead to substantial cost overrun, a substantial delay, or even project cancellation. Thus, we were able to assess whether the ambiguity was important, e.g., potentially leading to a significant delay of six months, or not important, e.g., only leading to a budget increase of $€ 100$. Moreover, after finalizing the series of interviews and meetings, we assessed during which interviews and meetings a particular ambiguity was brought up. If an ambiguity was brought up during several interviews and meetings, this clearly implied that the ambiguity had a project-wide relevance according to multiple actors and was not just the "favorite subject" of one actor.

After identifying the most important ambiguities, we determined, based on the interview data and our observations at the meetings, which actors were holding different frames regarding each of these ambiguities. The individual frames of these actors were identified by carefully studying the interviews we had with them, specifically by assessing how they interpreted the particular subject that the ambiguity concerned. We used the interviews with other actors, observations of the meetings, and written documentation, i.e., such as project documents, as supporting material for identifying the frames because these data sources often provided detailed additional information about the ambiguities and the frames of 
the individual actors. Thereafter, we identified the underlying actor attributes of the frames from the interview material, observations from meetings, project documents, information about the organization the interviewee was representing, and common sense. For each attribute, we performed this identification by explicitly examining the research questions proposed in Table 1. These research questions were formulated based on the theory that we discussed in our literature review of the attributes. By answering these specific research questions, we were able to accurately identify each attribute for each actor. Finally, we compared the frames that the different actors held regarding the ambiguities, compared the attributes of the actors involved, and determined which of these attributes were conflicting and which were not conflicting. Thereby, we elaborated a deeper understanding of why the individual frames differed and could lead to ambiguity in decision making.

Table 1. Questions posed to identify actor attributes regarding a specific discussion topic.

\begin{tabular}{|c|c|}
\hline Attributes & Questions \\
\hline Interests & What are the main ambitions or goals of the actor? \\
\hline Values & $\begin{array}{l}\text { Which moral principles does the actor hold as important } \\
\text { regarding the topic? Which criteria or boundary conditions } \\
\text { are used to evaluate the topic? }\end{array}$ \\
\hline Beliefs & $\begin{array}{l}\text { Which propositions or premises does the actor hold to be } \\
\text { true regarding the topic (even if there is no or } \\
\text { contradictory evidence)? }\end{array}$ \\
\hline $\begin{array}{l}\text { Backgro- } \\
\text { und }\end{array}$ & $\begin{array}{l}\text { Which expertise, education, or specific knowledge does the } \\
\text { actor have regarding the topic? Is the actor an expert or a } \\
\text { layman regarding the topic? }\end{array}$ \\
\hline $\begin{array}{l}\text { Experie- } \\
\text { nces }\end{array}$ & $\begin{array}{l}\text { From which (personal) historical situations does the actor } \\
\text { draw to interpret the topic? }\end{array}$ \\
\hline $\begin{array}{l}\text { Actor } \\
\text { position }\end{array}$ & $\begin{array}{l}\text { What is the societal or political position of the actor } \\
\text { regarding the topic compared to other relevant actors, in } \\
\text { terms of power or influence? }\end{array}$ \\
\hline
\end{tabular}

To further clarify the methods discussed previously, we provide Appendix 1 with a detailed example of how we identified the individual actors' frames and attributes from our research data. We extensively elaborate in Appendix 1 on how we came to the results concerning one of the important ambiguities identified in the Safety Buffer case.

\section{CASE STUDY 1: SAND ENGINE DELFLAND}

\section{Case description}

Over the past centuries, the sandy Holland coast of the Netherlands has been continuously retreating (see Van Koningsveld et al. 2008 for an overview of the historical development of the Dutch coast). The balance between the supply of sediment from fluvial and marine sources and the demand for sediment created by sea-level rise is negative (Mulder et al. 2011). To tackle the problem of coastal retreat, the Dutch government implemented the Dynamic Preservation policy: The sandy coastline has to be maintained at its 1990 position by performing periodic, relatively small-scale sand nourishments (Hillen and Roelse 1995). Currently, the annual sand nourishment volume for the Dutch coast has a target value of 12 million $\mathrm{m}^{3} /$ year, whereas an increase to at least 20 million $\mathrm{m}^{3} /$ year is needed to preserve the sediment balance of the Dutch coast (Mulder et al. 2011).
Sand Engine Delfland (in Dutch: Zandmotor) is an innovative sand nourishment pilot project of 21.5 million $\mathrm{m}^{3}$ near Ter Heijde in the Dutch province of South Holland (see Fig. 1). After a project development process of approximately 3 years, the Sand Engine peninsula was constructed between March and July 2011. It is a large-scale experiment to test the feasibility of mega-sized sand nourishments, which are anticipated to be more costeffective and less disturbing to the natural environment because of their long expected life span of 20-50 years. The Sand Engine is based on $\mathrm{BwN}$ design principles because the large amount of sand nourishment will spread along the coast by natural dynamics, i.e., waves, currents, and wind, causing the coast, i.e., both beach area and dunes, to expand in a rather natural way.

Fig. 1. Sand Engine Delfland (https://beeldbank.rws.nl, Rijkswaterstaat / Joop van Houdt).

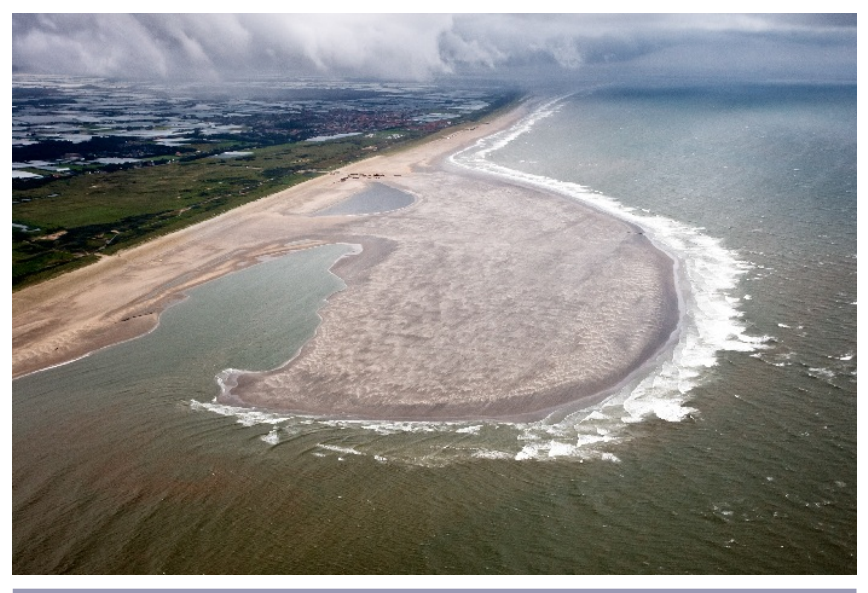

Currently, the Sand Engine is in the postconstruction monitoring phase. Because of its pilot status, the project will be monitored extensively to study whether mega-sized sand nourishments are capable of combining benefits for society, e.g., coastline maintenance and increased area for beach recreation, and development of the natural system, e.g., increased dune habitat for flora and fauna. Model calculations of various alternative Sand Engine designs have contributed to decision making by estimating morphological effects and changes in important indicators, especially coastline maintenance and dune development (Mulder and Tonnon 2010). However, because weather conditions are highly unpredictable, especially over a 20-50 year period, these estimations involve high levels of uncertainty. As a consequence, project development was susceptible to being hampered by several important framing differences regarding the impact of the Sand Engine.

\section{Results}

We identified three important ambiguous issues in the development process of the Sand Engine project between the project team and stakeholders. Although the project was successfully implemented in 2011, all ambiguities identified concerned issues that, according to multiple interviewees, could have hampered the Sand Engine project development process or might even have led to its cancellation (Van den Hoek et al. 2012).

The first ambiguity, between the Sand Engine project team and the action committee "Stop the Sand Engine," concerned the 
effect of the Sand Engine on swimmer safety (see Table 2). This discussion contained two main themes: (1) the effects of the Sand Engine peninsula on the physical swimming conditions, such as flow velocities; and (2) the risk that this would result in an unsafe situation and accidents. Although the project team drew on its background as an expert regarding sand nourishments to evaluate the issue of swimmer safety and presumed its morphological predictive models to be trustworthy, the action committee consisted of local residents with local knowledge based on personal swimming experiences. Both actors shared the value that they have a social responsibility for the safety of human beings in the vicinity of the Sand Engine. Furthermore, regarding the physical conditions in the coastal zone, both opposing parties had the same belief that these conditions were unpredictable to a large extent. However, regarding the swimmer safety situation, we identified a key framing difference. The project team had the positive frame that the Sand Engine was an innovative and socially acceptable pilot project. This frame was mainly based on the belief that the project would not lead to unsafe situations if proper precautionary measures were taken, such as additional training for beach lifeguards and prohibiting swimming in the vicinity of the Sand Engine. However, the action committee held a more skeptical frame: The Sand Engine's construction was socially unacceptable because the committee's belief was that it would have an adverse impact on swimming conditions. In the end, the project team had a more powerful position because it was supported by the national government, whereas the action committee was only supported by one political party.

The second ambiguity concerned the effect of the Sand Engine on beach recreation conditions (see Table 3). Specifically, there was a discourse between the project team and the action committee on the risk that dumped World War II ammunition would end up in the nourishment sand, posing a potential threat to beach tourists. The project team had its previously discussed positive frame, based on the belief that the construction of the Sand Engine would not lead to unsafe beach conditions. For instance, the project team drew on its experiences that constructors work with high-quality dredging ships equipped with special antiammunition grids and that previous nourishment did not have noteworthy ammunition incidents. However, the frame of the action committee was also quite skeptical regarding the risks of ammunition because it held the belief that it was a certainty that accidents would happen. This viewpoint was further supported by an informal report of an amateur military historian, which discusses the risks and some past experiences with ammunition on the beach.

The third ambiguity, between the Sand Engine project team and a drinking water stakeholder, concerned the effect of the artificial peninsula on groundwater levels and drinking water quality (see Table 4). Both actors shared the value that they have a social responsibility for the health and safety of humans. According to several interviewees and as stated in the project's EIA, the positive project team frame, i.e., that the project was socially acceptable, was based on the belief that the presence of the Sand Engine would not have substantial effects on groundwater levels and thus would have no impact on drinking water quality, if some minor precautionary measures were taken. Because of strict time constraints, the project team preferred a fast, rather limited assessment of the effects and had the belief that this was sufficient.
Table 2. Sand Engine ambiguity 1: about the effects on swimmer safety.

Actor Frames and actor attributes

Sand Engine project team

Frame: the Sand Engine is an innovative and socially acceptable pilot project. The project is vital to learn about possibilities for future coastal maintenance

(Attributes from which the frame originates)

Interest: to learn about how to improve coastal maintenance, while simultaneously creating opportunities for nature and recreation

Value: social responsibility for human safety

Belief: the physical conditions of the coastal zone are unpredictable

Belief: the Sand Engine will not cause unsafe swimming conditions if proper precautionary measures are taken Belief: morphological models generate trustworthy knowledge and prediction

Background: expert regarding flood infrastructure and sand nourishments

Actor position: powerful actor supported by the government

Action committee

Frame: the Sand Engine is a socially unacceptable initiative with adverse effects

(Attributes from which the frame originates) Interest: to protect recreational safety, by preventing Sand Engine implementation

Value: social responsibility for human safety

Belief: the physical conditions of the coastal zone are unpredictable

Belief: accidents are a certainty because of negatively influenced swimming conditions

Background: local residents of the project area

Experience: in the nearshore coastal zone, unexpected current conditions can occur

Actor position: less powerful coalition supported by one of the larger political party

However, the drinking water stakeholder was not satisfied, held the belief that the initiative would have a substantial impact, and demanded additional research. The stakeholder had the frame that the Sand Engine was an promising initiative, which might be acceptable after an accurate assessment of its impacts. Although the drinking water stakeholder had the expert background regarding this specific topic, the project team was not an expert regarding drinking water. Moreover, the project team had a less powerful actor position than the drinking water stakeholder regarding this specific issue. The drinking water stakeholder was an essential and necessary partner for the realization of the Sand Engine project because it was assigned with specific postimplementation maintenance and monitoring tasks.

\section{CASE STUDY 2: SAFETY BUFFER OYSTER DAM}

\section{Case description}

After the dramatic 1953 flooding of the southwestern provinces of the Netherlands, causing the deaths of more than 1800 people, the Dutch government commissioned the so-called Delta 
Table 3. Sand Engine ambiguity 2: about the effects on beach recreation conditions.

\begin{tabular}{l}
\hline \hline Actor Frames and actor attributes \\
\hline Sand Engine project team \\
Frame: the Sand Engine is an innovative and socially \\
acceptable pilot project. The project is vital to learn about \\
possibilities for future coastal maintenance \\
(Attributes from which the frame originates) \\
Interest: to learn about how to improve coastal maintenance, \\
while simultaneously creating opportunities for nature and \\
recreation \\
Value: social responsibility for human safety \\
Belief: the Sand Engine will not lead to unsafe beach \\
conditions \\
Background: expert regarding flood infrastructure and sand \\
nourishments \\
Experience: dredging companies use ships with \\
antiammunition grids \\
Experience: during regular nourishments similar to the Sand \\
Engine, there were no noteworthy incidents with ammunition \\
Actor position: powerful actor supported by the government
\end{tabular}

Action committee

Frame: the Sand Engine is a socially unacceptable initiative with adverse effects

(Attributes from which the frame originates)

Interest: to protect recreational safety, by preventing Sand

Engine implementation

Value: social responsibility for human safety

Belief: accidents are a certainty because nourishment sand contains ammunition

Background: local residents of the project area

Experience: ammunition, which is occasionally found on the beach, can be dangerous

Actor position: less powerful coalition supported by one of the larger political party

Committee to come up with a plan to improve the Dutch flood defense system to prevent future disasters (Kabat et al. 2009). The committee created a Delta Plan, which consisted of major dike improvements and the closure of several large tidal inlets. Over the years, the plans of the Delta Committee were implemented and became a worldwide premium example of flood protection. However, although new disasters have been prevented successfully, the Delta Works did have some partly unexpected negative side effects. Because of the closure of the Eastern Scheldt estuary by the Eastern Scheldt Storm Surge Barrier, the tidal movement in the estuary was reduced by $\sim 25 \%$ (Vranken et al. 1990, Mulder and Louters 1994). Furthermore, the inflow of fresh sediment from the North Sea into the water system of the Eastern Scheldt is negligible because of the storm surge barrier, whereas the redistribution of sediment toward the estuary's channels remains constant, i.e., the so-called Sand Hunger problem. This imbalance between the Eastern Scheldt morphology and hydrodynamics leads to an internal redistribution of sediments, causing the erosion of the existing salt marshes and mudflats, and thus the loss of valuable ecological habitat and natural foreshore protection.
Table 4. Sand Engine ambiguity 3: about the effects on groundwater level / drinking water quality.

\begin{tabular}{l}
\hline \hline Actor Frames and actor attributes \\
\hline Sand Engine project team \\
Frame: the Sand Engine is an innovative and socially \\
acceptable pilot project. The project is vital to learn about \\
possibilities for future coastal maintenance
\end{tabular}

(Attributes from which the frame originates)

Interest: to learn about how to improve coastal maintenance, while simultaneously creating opportunities for nature and recreation

Value: social responsibility for human health and safety Belief: the Sand Engine will not have substantial effects on the ground and drinking water, if some minor precautionary measures are taken

Background: not a specific expert regarding drinking water Actor position: less powerful actor as it requires the cooperation of the drinking water stakeholder for the project's maintenance and monitoring

Drinking water stakeholder Frame: the Sand Engine is an promising initiative, which might be acceptable after an accurate assessment of its impacts

(Attributes from which the frame originates) Interest: to supply safe drinking water of high quality to society

Value: social responsibility for human health and safety Belief: the Sand Engine will have substantial effects on groundwater levels and thus is a threat for the quality of the drinking water supply

Background: experts regarding drinking water

Actor position: powerful actor as it is a required project partner

The Oyster Dam is a so-called compartment work in the Eastern Scheldt (see Fig. 2). One of its main functions is to decrease the total area of the Eastern Scheldt to increase the tidal difference of ebb and flood tide, which had dropped after construction of the storm surge barrier. Thus, the Oyster Dam is partly a countermeasure for the negative influence of the storm surge barrier on the tidal movement. Additionally, it functions as a flood protection work for the hinterland. Because of the construction of the Oyster Dam and the Philips Dam, a second compartment work in the Eastern Scheldt, the decrease of the tidal difference was limited to $\sim 10 \%$ compared to the tidal difference before the construction of the Eastern Scheldt Storm Surge Barrier (Mulder and Louters 1994, Eelkema et al. 2012). However, the described Sand Hunger problem still remains unsolved.

Currently, the Oyster Dam requires maintenance because the stone layer on its slope has to be replaced. This maintenance work opened a window of opportunity for the pilot project Safety Buffer Oyster Dam (in Dutch: Veiligheidsbuffer Oesterdam): a sand nourishment of $425,000 \mathrm{~m}^{3}$ in front of the dam to reduce future maintenance efforts of the dam, while simultaneously restoring one of the eroded tidal flats to its historical state. Furthermore, an erosion-preventing artificial oyster reef will be constructed north of the planned nourishment area. Both 
measures are clear-cut examples of the application of $\mathrm{BwN}$ design principles: the initiative copes with the effects of the Sand Hunger problem using natural materials and dynamics, while concurrently strengthening the foundation of the Oyster Dam. The nourishment works were finished in October 2013. Nevertheless, a successful outcome of the pilot project has been far from certain because of the active involvement of multiple stakeholders and a project team that consists of two Dutch governmental agencies and a nongovernmental environmental interest organization, which all have different basic interests and preferences.

Fig. 2. Oyster Dam (https://beeldbank.rws.nl, Rijkswaterstaat / Joop van Houdt).

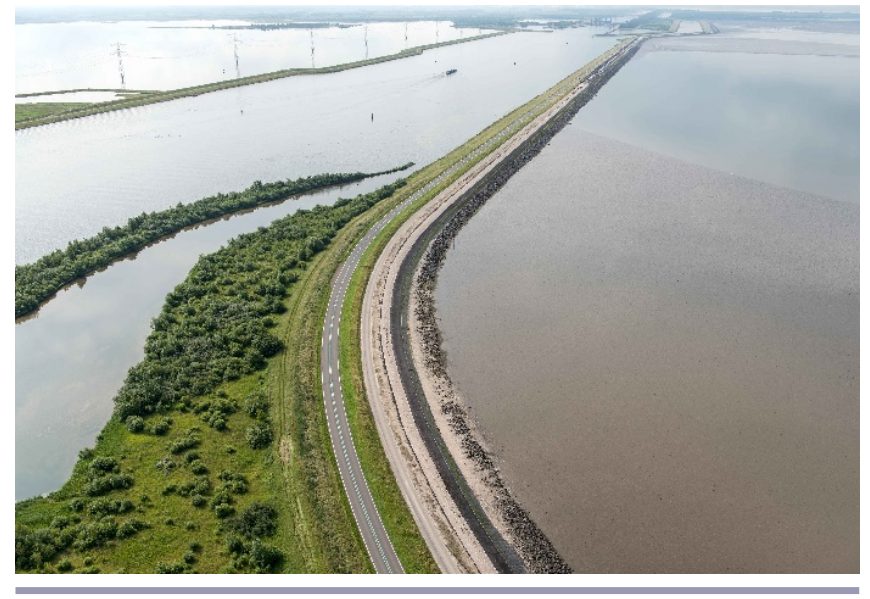

\section{Results}

We identified two important ambiguous issues in the development process of the Safety Buffer Oyster Dam project between the project team and two stakeholders. Although the stakeholders have dropped their opposition in the meanwhile and now accept the development of the project, the initial ambiguity could have significantly hampered the Safety Buffer's development process. An official appeal against the project could have delayed the initiative for at least six months.

The first ambiguity, between the Safety Buffer project team and the economically vital oyster sector, concerned the effects of the Safety Buffer nourishment on the oyster beds that are located in the vicinity of the project area (see Table 5). Although shellfish are able to filter a certain amount of sediment entering their gills, an excess will surely suffocate these organisms. During a recent nourishment pilot project, a mussel bed located nearby experienced some minor damage. Therefore, both the mussel and oyster sectors initially framed the Safety Buffer nourishment as an unacceptable initiative because they held the belief that large quantities of sand could damage their cultivated shellfish beds. Although several interviewees, including a representative from the mussel cultivation sector, indicated that they currently were confident that the nourishment would not have any adverse impacts, the oyster sector still held the strong belief that the Safety Buffer nourishment was potentially harmful. However, the oyster sector, contrary to the project team, did not have an expert background regarding flood management. Moreover, the project team held the value to protect stakeholder interests and formulated the following project boundary conditions: (1) the Safety Buffer was not allowed to have any negative effects on stakeholders, and (2) all unforeseen damage had to be fully compensated. Thus, the project team had the positive frame that the Safety Buffer was a socially acceptable project because the team intended to fulfill the boundary conditions and held the belief that the expert judgment of the project's effects was trustworthy. Furthermore, the project team also referred to recent successful experiences with nourishment pilots in the Eastern Scheldt. Regarding the difference with the oyster sector, the actor positions seemed to be rather equal: Both the project team and the oyster sector indicated that they did not have sufficient power to overrule the other actor.

Table 5. Safety Buffer Oyster Dam ambiguity 1: about the effects of the nourishment on oyster beds.

Actor Frames and actor attributes

Safety Buffer project team

Frame: the Safety Buffer is an innovative and socially acceptable pilot project. The project is vital to learn about possibilities for future dike maintenance and dealing with the effects of the Sand Hunger

(Attributes from which the frame originates)

Interest: to learn about how to improve dike maintenance, while simultaneously aiming to improve the Eastern Scheldt estuary's natural, recreation, and user quality

Value: social responsibility for the well-being of the Eastern Scheldt estuary

Value: responsibility not to harm external stakeholders' interests

Belief: the Safety Buffer will not have adverse effects on the shellfish beds

Belief: expert judgment yields trustworthy predictions

Background: expert regarding flood infrastructure and sand nourishments

Experience: positive results of nourishment pilots in recent years

Actor position: although a powerful actor supported by the government, they claim to be unable to overrule the economically vital oyster sector

Oyster sector

Frame: the Safety Buffer is an unacceptable initiative because of its potential adverse impacts on the oyster sector, although the degrading quality of the estuary is acknowledged

(Attributes from which the frame originates) Interest: to maximize the profit of the oyster sector Value: social responsibility for the well-being of the Eastern Scheldt estuary

Belief: the Safety Buffer will almost certainly have negative effects on the oyster beds

Background: economic users of the area, nonexperts regarding sand nourishments

Experience: during a previous pilot, a mussel bed suffered some minor damage

Actor position: economically vital actor, although without formal power to prevent project implementation 
The second ambiguity, between the Safety Buffer project team and an environmental interest group, concerned the effects of the Safety Buffer nourishment on the benthic organisms currently living in the soil of the existing tidal flat (see Table 6). Similar to the Sand Engine framing difference on swimmer safety, this discussion contained two main themes: (1) the effects of the nourishment on the living conditions of the benthic organisms and (2) the acceptability of the implementation of a project with a major impact on those living conditions. Both actors shared the value that the well-being of the Eastern Scheldt system was important. Furthermore, regarding the living conditions, both opposing parties had the same belief: Most benthic organisms living in the soil of a nourished area would die. However, regarding the acceptability of the project, there was a key framing difference. The project team had the frame that the project was acceptable, based on the beliefs that the quality of the nourished tidal habitat would improve in the future and that valuable knowledge would be generated for future initiatives to preserve the Eastern Scheldt system. Initially, the environmental interest group had a quite different view on the acceptability of the project. Although it acknowledged that measures were needed to cope with the effects of the Sand Hunger, the group argued that it was unacceptable to nourish large quantities of sand on top of the benthic organisms. This frame was mainly based on the incorrect presumption that the total area of the existing tidal flat would be nourished. However, the project team, an expert in sand nourishment designs, intended to only nourish half of the existing tidal flat and use natural dynamics to gradually spread the sand toward the other part of the tidal flat. Furthermore, experiences with recent nourishment pilots in the Eastern Scheldt showed that the benthic organisms reclaimed their habitat within due time. Regarding this specific issue, the actor positions were rather unclear. Although the project team was powerful and supported by the government, the environmental interest group was an independent actor that could appeal against initiatives that discomforted the group.

\section{DISCUSSION}

We first discuss which of the actor attributes seems to be the conflicting focal element from which the ambiguity in our case studies originates. Second, we discuss that an actor's background seems to influence the perceived legitimacy of his or her viewpoint regarding the ambiguity. Finally, we elaborate on what these two findings imply for how ambiguity is and should be coped with in our case study projects.

From which actor attributes does the ambiguity originate?

In the two previous sections, we identified five ambiguous issues that could have potentially hampered the development of our two $\mathrm{BwN}$ case study projects. Despite the fact that these five ambiguities all concern a different issue, our results suggest a distinct similarity regarding the underlying actor attributes leading to ambiguity: The beliefs of the actors involved are contradictory. In terms of the discussed work of Dewulf and Bouwen (2012), the actor attribute beliefs seems to be the conflicting focal element from which the ambiguity arises.

Regarding both the ambiguities about swimmer safety and beach recreation conditions, the Sand Engine project team's positive frame was primarily based on the beliefs that (1) the project would not cause unsafe recreational conditions if proper precautionary
Table 6. Safety Buffer Oyster Dam ambiguity 2: about the acceptability (benthic organisms).

Actor Frames and actor attributes

Safety Buffer project team

Frame: the Safety Buffer is an innovative and socially acceptable pilot project. The project is vital to learn about possibilities for future dike maintenance and dealing with the effects of the Sand Hunger

(Attributes from which the frame originates)

Interest: to learn about how to improve dike maintenance, while simultaneously aiming to improve the Eastern Scheldt estuary's natural, recreation, and user quality

Value: social responsibility for the well-being of the Eastern Scheldt estuary

Belief: benthic organisms currently living in the nourished area will die, but the tidal flat habitat will improve in the future Belief: implementing the preferred design, partially nourishing the tidal flat, will yield knowledge that can be used for future initiatives

Background: expert regarding flood infrastructure and sand nourishments

Experience: positive results of nourishment pilots in recent years

Actor position: powerful actor supported by the government

Environmental interest group

Frame: implementation of the Safety Buffer is unacceptable because of its initial adverse impacts on the natural environment

(Attributes from which the frame originates) Interest: to protect the existing natural environment Value: social responsibility for the natural environment Belief: the benthic organisms currently living in the nourished tidal flat area will die

Belief: the full tidal flat area, not just a part, will be nourished Background: laypersons regarding sand nourishments

Actor position: independent actor that can appeal against the project, potentially causing a delay of six months

measures were taken, and that (2) morphological models provided trustworthy predictions for these conditions. The action committee's skeptical frame was based on the belief that accidents were a certainty because of negatively influenced swimming conditions. The ambiguity between the Safety Buffer project team and the oyster sector was also a contradiction of beliefs. Whereas the project team's positive frame was based on the beliefs that the Safety Buffer would not have adverse effects on the shellfish beds and that expert judgment provided trustworthy predictions, the oyster sector held the belief that the Safety Buffer almost certainly would have adverse impacts on the cultivated shellfish beds. The second Safety Buffer ambiguity, about the acceptability of the project despite initial negative impacts on benthic organisms, was caused by the incorrect presumption, i.e., a belief, of the environmental interest group that the total area of the tidal flat would be nourished. However, the project team's positive frame was based on the belief that its well-considered preferred design had limited impacts on the existing benthic organisms and would improve the habitat in the future. 
The ambiguity about the effect of the Sand Engine on drinking water safety was a special case because, contrary to the other four ambiguous issues, the project team was not the actor that held the most powerful position regarding this specific issue. Nevertheless, also in this special case, the beliefs of the actors involved were contradictory. The Sand Engine project team held a strong belief that the effects on the groundwater and drinking water were negligible, although there was only limited knowledge available. However, the drinking water stakeholder, an expert regarding this specific issue, demanded an additional extensive impact assessment because its belief was that the project might have substantial effects on the quality of the drinking water supply.

The ambiguity in $\mathrm{BwN}$ project development does not seem to originate from conflicting values or interests of the actors involved. Thacher (2001) suggests that, when particular actors aim to collaborate, problems often occur because of a conflict over differing values. However, although this may be generally true, in the two cases we studied, the project teams and the stakeholders shared similar values, such as the social responsibility for human safety or the natural environment. Because these moral principles were collectively shared, this implies that ambiguity in the project development of our cases did not originate from conflicting values. Interests is yet another attribute from which ambiguity could originate because in the field of intergroup conflict research, diverging and incompatible interests, goals, and ambitions have been a main focus of attention (see, e.g., Campbell 1965, Lewicki et al. 1992, Bornstein 2003). However, in the specific cases we studied, we observed that the interests of the actors involved were dissimilar but not contradictory. This consideration suggests that, regarding the interests held by the different parties, there is a situation of equifinal meaning (sensu Donnellon et al. 1986), a common ground for the actors involved. In the Sand Engine case, the action committee's interest was to protect the safety of local swimmers and beach recreants, whereas the drinking water stakeholder was responsible for the quality of the drinking water supply. In the Safety Buffer case, the oyster sector defended its economic interests, whereas the environmental interest group's interest was to protect the existing natural environment. The main interest of the two project teams involved was to learn about how to improve the current flood management practices, while simultaneously creating opportunities for users of the area, the natural environment, and recreation. This project team interest was not precisely the same as the stakeholders' interests, but it was also clear that they did not interfere with each other. Hence, we argue that although the interests of the actors involved were dissimilar, they did not seem to be the conflicting focal element from which the ambiguity in our case studies originated.

\section{Whose beliefs seem to be perceived as more legitimate?}

Although we found that the ambiguity in our two case studies seemed to originate from a difference between the beliefs of the actors, our results revealed that there was yet another actor attribute that seemed to influence the perceived legitimacy of those beliefs, namely the actor's background. For each of the five ambiguous issues identified, we observed that one actor had an expert background regarding the issue and the other actor was a group of laypersons. Although the expert's previous experiences seemed to be perceived as a legitimate source of knowledge, the experiences and stories of the lay actor were often not taken into account and seemed to be considered as less legitimate.

Regarding the Sand Engine ambiguities about swimming safety and beach recreation safety, the project team was the expert on sand nourishments and their effects. It further supported its positive frame by pointing at verifiable past experiences with sand nourishments, which were carried out without noteworthy incidents. The action committee was a group of laypersons regarding the topic of flood infrastructure and sand nourishments. It supported a skeptical frame with stories of allegedly negative experiences with sand nourishments and with the aforementioned informal report by an amateur military historian. Even though the project team listened to these stories at the public meetings and was acquainted with the contents of the report, our observations suggest that these were not fully taken into account by the project team. During the interviews, the project team indicated that it "did not actively, over and over again, engage in conversation [with the action committee]" and instead focused on "good, honest information,"i.e., on knowledge that it perceived as legitimate from its particular perspective. Furthermore, our document study revealed that the report was not taken into account because its story line lacked verifiable evidence for a causal relationship between the Sand Engine's construction and future incidents with ammunition. For the ambiguity about drinking water safety, the project team had significantly less expertise than the specialized drinking water stakeholder. In the end, the drinking water expert's belief was perceived as the more legitimate one, and the project team had to change its belief that the project would not have a substantial impact on the drinking water situation.

Similarly, in the Safety Buffer case, the project team was the expert regarding sand nourishments and their effects and development. Although the oyster sector and environmental interest group could be regarded as experts regarding the oyster trade and natural systems, they were laypersons regarding sand nourishments and the likelihood of damage because of a specific sand nourishment. As a justification of its positive beliefs, the project team enthusiastically referred to successful experiences with recent nourishment pilots in the Eastern Scheldt. To the contrary, the oyster sector referred to a negative experience with a damaged mussel bed, presumably because of one of the recent pilot projects, and argued that its oyster beds could suffer similar damage. However, during our interviews, the shellfish sector indicated that it was almost impossible for it to prove that there was a causal relationship between damaged shellfish beds and nourishment activities. Hence, the previous examples illustrate that it is difficult for nonexperts to have their experiences and stories taken into account by the expert actors in collective decision making.

In the field of risk assessment, the difference between experts and laypersons has been studied in detail. For instance, Slovic (1999) argues that although experts are often characterized as objective, analytic, wise, and rationally based on "the real risks," in contrast, the lay public is seen to rely on "perceptions of risk" that are subjective, often hypothetical, emotional, foolish, and irrational. Thus, although an expert is considered to evaluate risks using "objective" beliefs, the layperson can easily form "subjective" emotional beliefs. However, there is no consensus about whether 
the expert's or the layperson's viewpoint is the more legitimate one. Although Slovic (1987) argues that the basic conceptualization of risk by laypeople is much richer than that of experts and reflects legitimate concerns, Kuran and Sunstein (1999) disagree and state that nonexpert individuals often lack knowledge and expertise to make a reliable judgment. On the other hand, Klinke and Renn (2002) propose a dual approach to risk management, stating that the identification of risks and the formulation of risk evaluation criteria should be based on the social concerns of the public, whereas the "objective" evaluation of the magnitude of those risks should be performed by experts. However, involving the emotions and feelings of laypeople in the actual decision making can be essential (Thacher 2009). Lidskog (2008) argues that including citizens in the evaluation of risk in collective decision making is necessary because citizens' opinions and reflections can enrich expert advice and recommendations.

The results of our research suggest that in the current practice of our two case study projects, an actor's background seems to determine whether his or her beliefs are taken into account in the decision-making process. The beliefs and experiences of experts seem to be perceived as more legitimate than the beliefs and experiences of local lay actors, which suggests that experts have a more privileged and powerful position in multiactor decision making. We will show that this consideration has major implications for the way in which we deal with ambiguity in collective processes.

\section{What are the implications for coping with ambiguity in Building with Nature projects?}

In the ideal situation, coping with ambiguity implies addressing the underlying framing difference in a multiactor participatory process because this denotes that it is accepted that there are multiple ways of making sense of an issue (Brugnach et al. 2011, Brugnach and Ingram 2012). However, judging which specific strategy to use for addressing a particular ambiguity depends on many different factors (Maurel 2003, HarmoniCOP 2005). We observed that in the current practice of our two BwN case study projects, the actor positions, i.e., the actors' power, have major consequences for the way the ambiguity is dealt with.

Although the philosophy of the BwN approach advocates that active involvement of stakeholders is both required and beneficial (De Vriend and Van Koningsveld 2012), we observed that, compared to the valuable insights in the literature on participatory processes, the actual participation of stakeholders often remains at a low level in the daily practice of our $\mathrm{BwN}$ case study projects. Such a low level of participation is characterized by top-down communication and an information flow that is mainly one way (Rowe and Frewer 2000). In the Sand Engine case, public meetings were the main method to involve stakeholders. Although those present were invited to express their views on the initiative, the described meetings mainly consisted of several extensive presentations to update the public on project development activities that had already occurred without stakeholders being involved. Thus, the level of stakeholder participation in the project generally seemed to be limited to informing (sensu Arnstein 1969). Furthermore, when confronted with the ambiguities about the effects of the Sand Engine on swimmer and beach recreation safety, the role of the action committee was basically reduced to that of a spectator (sensu Fung 2006). Instead of solving the underlying framing difference, the project team prevented a hampered development process by using its power (see Tables 2 and 3 ) to let its own frame prevail and neglected the action committee's frame; that is, because there was governmental support, it was decided to implement the project despite persistent opposition. In terms of stakeholder participation, this mainly resembled the lowest form of involvement, namely manipulation (sensu Arnstein 1969). To the contrary, regarding the ambiguity about drinking water safety, the project team had a less powerful position (see Table 4), which meant that a form of partnership (sensu Arnstein 1969) was needed to solve the ambiguity. The drinking water issue was first addressed by doing the required additional impact assessment. As a result of this assessment, the project team changed its belief that the project would not have a substantial impact on the drinking water situation. In the end, the two actors started a negotiation that eventually resulted in the installation of a pumping station to prevent drinking water problems. Hence, our results suggest that, in the Sand Engine case, the level of stakeholder participation in a situation of ambiguity is related to the relative power that the actors have.

Conversely, in the Safety Buffer case, the project team indicated that it strived for a partnership in which project developers and stakeholders jointly would make plans and develop strategies (sensu Fung 2006). Although stakeholders were invited to project meetings to jointly create an inventory of design requirements and preferences, the actual design process was outsourced to an external company. Although stakeholders were consulted about the design alternatives during a sounding board meeting, the project team explicitly expressed that it would make the final decisions. Hence, we argue that the actual level of stakeholder participation is best characterized as consulting (sensu Arnstein 1969). When confronted with ambiguity, power relations, which are rather unclear in the Safety Buffer case, seem to have influenced the way in which participation took place. Regarding the ambiguity about the project's effects on the oyster beds, both the project team and oyster sector maneuvered themselves to an underdog position by stating that they were unable to overrule the other actor (see Table 5). Eventually, the project team chose to initiate a renewed interactive process, a sort of partnership (sensu Arnstein 1969), to jointly come up with a new set of design alternatives. Regarding the benthic organisms issue, the environmental interest group was an independent organization of concerned citizens who could appeal against projects that discomforted them (see Table 6). The project team engaged in extensive persuasive conversations with the environmental interest group to convince it of the project's positive intentions and to change the previously discussed incorrect belief regarding the size of the nourishment area. In terms of stakeholder participation, the involvement of the environmental interest group was basically limited to informing (sensu Arnstein 1969).

Moreover, we observed, for all five ambiguous issues identified in our two case studies, that the powerful actor was also the expert regarding the issue being framed. Although these powerful experts supported their beliefs with scientific knowledge that was perceived as legitimate, the laypersons involved were often unable to have their beliefs taken into account in the decision-making process as illustrated previously. In short, our observations suggest that powerful actors with access to scientific knowledge and expertise were privileged over laypersons in the decision- 
making processes of our two BwN case study projects. However, the knowledge of both experts and nonexperts needs to be assimilated into the collective decision-making processes in $\mathrm{BwN}$ initiatives, because active participation of stakeholders leads to better and more legitimate decisions (e.g., Fiorino 1990, Randolph and Bauer 1999, Beierle 2002, Huitema et al. 2009), to create a shared knowledge base that is perceived as legitimate by all actors involved.

\section{CONCLUSIONS}

We studied the origin of ambiguity in the development process of projects based on $\mathrm{BwN}$ design principles. We investigated the attributes underlying the frames of the actors that held diverging views on the issue being framed. Our findings suggest that ambiguity in multistakeholder decision settings, such as $\mathrm{BwN}$ projects, originates from a contradiction between the beliefs of the actors involved. Actors occasionally attempt to support their beliefs with reports and stories of past experiences. However, whereas knowledge and experiences of the powerful experts seem to be perceived as legitimate and verifiable, our observations suggest that knowledge and past experiences of nonexperts, although these can be very valuable, are not taken into account in the decision-making process because they are hard to verify. For instance, we provided examples showing how difficult it was for nonexperts to provide verifiable evidence that the project under consideration might have adverse consequences. Moreover, our observations suggest that the actor positions in terms of power are currently the most important determinant for how to cope with ambiguity. These findings suggest that in the current practice of nature-inclusive flood infrastructure projects, powerful actors with access to scientific knowledge are privileged over lay actors with local knowledge and experiences. However, human interactions can also shape frames and change an actor's attributes. Hence, although we have analyzed differences among the frames of individual actors or a group of actors at a particular moment in time, future research will benefit from considering the interactional framing processes through which frames are shaped.

Carrying on a participatory process could be a promising means to align diverging beliefs in multiactor project development to prevent or solve ambiguity (Brugnach and Ingram 2012). However, our results indicate that, currently, project teams and experts have a much stronger position than nonexpert actors. For instance, even though the Safety Buffer case can be characterized as a participatory process in which stakeholder requirements were taken into account as much as possible, the project team explicitly stated that it would make the final decision regarding the implementation of the initiative. This example points out that even in cases where stakeholders are actively included in the participatory process, they are not necessarily granted decisive influence regarding the action path chosen. This consideration implies that an important challenge would be to pay more attention to the rules underlying participatory processes to come to more democratic knowledge coproduction processes. The suggested way of doing so is to establish a decision-making setting in which the debate is open and free among all parties involved and affected, and all opinions are heard and respected (RichardFerroudji and Barreteau 2012).

The results of our research demonstrate that it is difficult to bring the beliefs and past experiences of stakeholders to collective decision making in nature-inclusive flood management.
Currently, the lay public is regularly invited to all kinds of public consultation activities, e.g., the public meetings in the Sand Engine case, but it is rarely included in the knowledge production process (Lidskog 2008). To come to a scientifically valid, socially robust, and context-specific knowledge base, different knowledge sources, i.e., expert and local knowledge, should be integrated in participatory processes (Hommes et al. 2009). To share power and responsibility between the government and local stakeholders, it is a requirement to generate and use knowledge together (Berkes 2009). In an open and transparent participatory process, actors can gradually develop a set of mutually shared beliefs regarding ambiguous issues and jointly develop knowledge that is perceived as legitimate by all those involved. If such knowledge from different sources and disciplines is used to define a problem and identify possible solutions, the final decision is the result of the interactive process of the group of participating actors instead of a single rational actor (Brugnach and Ingram 2012). Such equitable participatory processes, i.e., in which an equifinal set of interests, moral principles, beliefs, and the required legitimate knowledge base are developed and used by the actors involved, are likely to lead to better decisions and increased public support for promising $\mathrm{BwN}$ initiatives.

\section{Responses to this article can be read online at: http://www.ecologyandsociety.org/issues/responses. $\mathrm{php} / 6416$}

\section{Acknowledgments:}

We thank the foundation EcoShape, responsible for the execution of the Dutch national research program 'Building with Nature', for the funding of this research, and our colleagues in the research program for the interesting discussions about the role of uncertainty and ambiguity in projects based on $B w N$ design principles. Furthermore, we acknowledge the members of the Kennisteam Oesterdam for their support, and the interviewees for their time and effort to contribute to our research. We thank Theo Vulink for his contributions as interviewer in the Safety Buffer Oyster Dam case, and three anonymous reviewers and the subject editor for their insightful comments on earlier versions of this manuscript.

\section{LITERATURE CITED}

Arnstein, S. R. 1969. A ladder of citizen participation. Journal of the American Institute of Planners 35(4):216-224.

Beierle, T. C. 2002. The quality of stakeholder-based decisions. Risk Analysis 22(4):739-749. http://dx.doi.org/10.1111/0272-4332.00065

Benford, R. D., and D. A. Snow. 2000. Framing processes and social movements: an overview and assessment. Annual Review of Sociology 26:611-639. http://dx.doi.org/10.1146/annurev.soc.26.1.611

Berkes, F. 2009. Evolution of co-management: role of knowledge generation, bridging organizations and social learning. Journal of Environmental Management 90(5):1692-1702. http://dx.doi. org/10.1016/j.jenvman.2008.12.001

Bornstein, G. 2003. Intergroup conflict: individual, group, and collective interests. Personality and Social Psychology Review 7 (2):129-145. http://dx.doi.org/10.1207/S15327957PSPR0702_129-145 
Bouwen, R., and T. Taillieu. 2004. Multi-party collaboration as social learning for interdependence: developing relational knowing for sustainable natural resource management. Journal of Community \& Applied Social Psychology 14(3):137-153. http:// dx.doi.org/10.1002/casp.777

Brugnach, M., A. Dewulf, H. J. Henriksen, and P. van der Keur. 2011. More is not always better: coping with ambiguity in natural resources management. Journal of Environmental Management 92 (1):78-84. http://dx.doi.org/10.1016/j.jenvman.2010.08.029

Brugnach, M., A. Dewulf, C. Pahl-Wostl, and T. Taillieu. 2008. Toward a relational concept of uncertainty: about knowing too little, knowing too differently, and accepting not to know. Ecology and Society 13(2): 30. [online] URL: http://www.ecologyandsociety. org/vol13/iss2/art30/

Brugnach, M., and H. Ingram. 2012. Ambiguity: the challenge of knowing and deciding together. Environmental Science \& Policy 15(1):60-71. http://dx.doi.org/10.1016/j.envsci.2011.10.005

Brummans, B. H. J. M., L. L. Putnam, B. Gray, R. Hanke, R. J. Lewicki, and C. Wiethoff. 2008. Making sense of intractable multiparty conflict: a study of framing in four environmental disputes. Communication Monographs 75(1):25-51. http://dx.doi. org/10.1080/03637750801952735

Campbell, D. T. 1965. Ethnocentric and other altruistic motives. Pages 283-301 in D. Levine, editor. Nebraska Symposium on Motivation. University of Nebraska Press, Lincoln, Nebraska, USA.

Carragee, K. M., and W. Roefs. 2004. The neglect of power in recent framing research. Journal of Communication 54 (2):214-233. http://dx.doi.org/10.1093/joc/54.2.214

De Boer, J., J. A. Wardekker, and J. P. van der Sluijs. 2010. Framebased guide to situated decision-making on climate change. Global Environmental Change 20(3):502-510. http://dx.doi. org/10.1016/j.gloenvcha.2010.03.003

De Vriend, H. J., and M. van Koningsveld. 2012. Building with Nature: thinking, acting and interacting differently. EcoShape, Building with Nature, Dordrecht, the Netherlands.

Dewulf, A., and R. Bouwen. 2012. Issue framing in conversations for change: discursive interaction strategies for "doing differences." Journal of Applied Behavioral Science 48(2):168-193. http://dx.doi.org/10.1177/0021886312438858

Dewulf, A., M. Craps, R. Bouwen, T. Taillieu, and C. Pahl-Wostl. 2005. Integrated management of natural resources: dealing with ambiguous issues, multiple actors and diverging frames. Water Science and Technology 52:115-124.

Dewulf, A., M. Craps, and G. Dercon. 2004. How issues get framed and reframed when different communities meet: a multilevel analysis of a collaborative soil conservation initiative in the Ecuadorian Andes. Journal of Community \& Applied Social Psychology 14(3):177-192. http://dx.doi.org/10.1002/casp. 772

Dewulf, A., B. Gray, L. Putnam, R. Lewicki, N. Aarts, R. Bouwen, and C. van Woerkom. 2009. Disentangling approaches to framing in conflict and negotiation research: a meta-paradigmatic perspective. Human Relations 62(2):155-193. http://dx.doi. org/10.1177/0018726708100356
Donnellon, A., B. Gray, and M. G. Bougon. 1986. Communication, meaning, and organized action. Administrative Science Quarterly 31(1):43-55. http://dx.doi.org/10.2307/2392765

Eelkema, M., Z. B. Wang, and A. Hibma. 2012. Ebb-tidal morphology in response to a storm surge barrier. Pages 137-141 in W. M. Kranenburg, E. M. Horstman, and K. M Wijnberg, editors. Jubilee Conference Proceedings NCK Days 2012, 13-16 March 2012, University of Twente, Enschede, the Netherlands. http://dx.doi.org/10.3990/2.184

Fiorino, D. J. 1990. Citizen participation and environmental risk: a survey of institutional mechanisms. Science, Technology, \& Human Values 15(2):226-243. http://dx.doi.org/10.1177/016224399001500204

Fung, A. 2006. Varieties of participation in complex governance. Public Administration Review 66:66-75. http://dx.doi.org/10.1111/ j.1540-6210.2006.00667.X

Gamson, W. A., and A. Modigliani. 1989. Media discourse and public opinion on nuclear power: a constructionist approach. American Journal of Sociology 95(1):1-37. http://dx.doi. org/10.1086/229213

Gleick, P. H. 2000. The changing water paradigm: a look at twenty-first century water resources development. Water International 25(1):127-138. http://dx.doi.org/10.1080/02508060008686804

Gray, B. 2004. Strong opposition: frame-based resistance to collaboration. Journal of Community \& Applied Social Psychology 14(3):166-176. http://dx.doi.org/10.1002/casp.773

Harmonising Collaborative Planning (HarmoniCOP). 2005. Learning together to manage together-improving participation in water management. USF, University of Osnabrück, Osnabrück, Germany.

Hillen, R., and P. Roelse. 1995. Dynamic preservation of the coastline in the Netherlands. Journal of Coastal Conservation 1:17-28. http://dx.doi.org/10.1007/BF02835558

Hoekstra, A. Y. 2000. Appreciation of water: four perspectives. Water Policy 1(6):605-622. http://dx.doi.org/10.1016/S1366-7017 (99)00013-6

Hommes, S., J. Vinke-de Kruijf, H. S. Otter, and G. Bouma. 2009. Knowledge and perceptions in participatory policy processes: lessons from the Delta-region in the Netherlands. Water Resources Management 23(8):1641-1663. http://dx.doi.org/10.1007/ s11269-008-9345-6

Huitema, D., E. Mostert, W. Egas, S. Moellenkamp, C. PahlWostl, and R. Yalcin. 2009. Adaptive water governance: assessing the institutional prescriptions of adaptive (co-)management from a governance perspective and defining a research agenda. Ecology and Society 14(1): 26. [online] URL: http://www.ecologyandsociety. org/vol14/iss 1/art26/

Kabat, P., L. O. Fresco, M. J. F. Stive, C. P. Veerman, J. S. L. J. van Alphen, B. W. A. H. Parmet, W. Hazeleger, and C. A. Katsman. 2009. Dutch coasts in transition. Nature Geoscience 2:450-452. http://dx.doi.org/10.1038/ngeo572

Kaplan, S. 2008. Framing contests: strategy making under uncertainty. Organization Science 19(5):729-752. http://dx.doi. org/10.1287/orsc. 1070.0340 
Klinke, A., and O. Renn. 2002. A new approach to risk evaluation and management: risk-based, precaution-based, and discoursebased strategies. Risk Analysis 22(6):1071-1094. http://dx.doi. org/10.1111/1539-6924.00274

Kuran, T., and C. R. Sunstein. 1999. Availability cascades and risk regulation. Stanford Law Review 51(4):683-768. http://dx.doi. org/10.2307/1229439

Lewicki, R. J., S. E. Weiss, and D. Lewin. 1992. Models of conflict, negotiation and third party intervention: a review and synthesis. Journal of Organizational Behavior 13(3):209-252. http://dx.doi. org/10.1002/job.4030130303

Lidskog, R. 2008. Scientised citizens and democratised science. Re-assessing the expert-lay divide. Journal of Risk Research 11 (1-2):69-86. http://dx.doi.org/10.1080/13669870701521636

Maurel, P., editor. 2003. Public participation and the European Water Framework Directive: role of information and communication tools. WorkPackage 3 report of the HarmoniCOP project - Harmonising Collaborative Planning, Cemagref, Montpellier, France.

Mulder, J. P. M., S. Hommes, and E. M. Horstman. 2011. Implementation of coastal erosion management in the Netherlands. Ocean \& Coastal Management 54(12):888-897. http://dx.doi.org/10.1016/j.ocecoaman.2011.06.009

Mulder, J. P. M., and T. Louters. 1994. Changes in basin geomorphology after implementation of the Oosterschelde estuary project. Hydrobiologia 282-283(1):29-39. http://dx.doi. org/10.1007/BF00024619

Mulder, J. P. M., and P. K. Tonnon. 2010. "Sand Engine": background and design of a mega-nourishment pilot in the Netherlands. Pages 3805-3814 in J. McKee Smith and P. Lynett, editors. Proceedings of the 32nd Conference on Coastal Engineering (30 June-5 July 2010, Shanghai, China). International Conference on Coastal Engineering, Los Angeles, California, USA.

Nisbet, M. C. 2009. Communicating climate change: why frames matter for public engagement. Environment: Science and Policy for Sustainable Development 51(2):12-23. http://dx.doi.org/10.3200/ ENVT.51.2.12-23

Nisbet, M. C., and C. Mooney. 2007. Framing science. Science 316:56. http://dx.doi.org/10.1126/science.1142030

Pahl-Wostl, C., M. Craps, A. Dewulf, E. Mostert, D. Tabara, and T. Taillieu. 2007a. Social learning and water resources management. Ecology and Society 12(2): 5. [online] URL: http:// www.ecologyandsociety.org/vol12/iss2/art5/

Pahl-Wostl, C., P. Jeffrey, N. Isendahl, and M. Brugnach. 2011. Maturing the new water management paradigm: progressing from aspiration to practice. Water Resources Management 25 (3):837-856. http://dx.doi.org/10.1007/s11269-010-9729-2

Pahl-Wostl, C., J. Sendzimir, P. Jeffrey, J. Aerts, G. Berkamp, and K. Cross. 2007b. Managing change toward adaptive water management through social learning. Ecology and Society 12(2): 30. [online] URL: http://www.ecologyandsociety.org/vol12/iss $2 /$ $\underline{\operatorname{art} 30}$
Randolph, J., and M. Bauer. 1999. Improving environmental decision-making through collaborative methods. Review of Policy Research 16(3-4):168-191. http://dx.doi.org/10.1111/j.1541-1338.1999. tb00882.x

Renn, O., A. Klinke, and M. van Asselt. 2011. Coping with complexity, uncertainty and ambiguity in risk governance: a synthesis. AMBIO 40(2):231-246. http://dx.doi.org/10.1007/ $\underline{\mathrm{s} 13280-010-0134-0}$

Richard-Ferroudji, A., and O. Barreteau. 2012. Assembling different forms of knowledge for participatory water management: insights from the Concert'eau game. Pages 97-120 in C. Claeys and M. Jacqué, editors. Environmental democracy facing uncertainty. Peter Lang, Brussels, Belgium.

Richter, B. D., R. Mathews, D. L. Harrison, and R. Wigington. 2003. Ecologically sustainable water management: managing river flows for ecological integrity. Ecological Applications 13 (1):206-224. http://dx.doi.org/10.1890/1051-0761(2003)013[0206: ESWMMR]2.0.CO;2

Rowe, G., and L. J. Frewer. 2000. Public participation methods: a framework for evaluation. Science, Technology, \& Human Values 25(1):3-29. http://dx.doi.org/10.1177/016224390002500101

Schön, D., and M. Rein. 1994. Frame reflection: towards resolution of intractable policy controversies. Basic Books, New York, New York, USA.

Slovic, P. 1987. Perception of risk. Science 236:280-285. http://dx. doi.org/10.1126/science.3563507

Slovic, P. 1999. Trust, emotion, sex, politics, and science: surveying the risk-assessment battlefield. Risk Analysis 19 (4):689-701. http://dx.doi.org/10.1111/j.1539-6924.1999.tb00439. $\underline{\mathrm{X}}$

Snow, D. A., E. B. Rochford, Jr., S. K. Worden, and R. D. Benford. 1986. Frame alignment processes, micromobilization, and movement participation. American Sociological Review 51 (4):464-481. http://dx.doi.org/10.2307/2095581

Thacher, D. 2001. Conflicting values in community policing. Law \& Society Review 35(4):765-798. http://dx.doi.org/10.2307/3185416

Thacher, D. 2009. The cognitive foundations of humanistic governance. International Public Management Journal 12 (2):261-286. http://dx.doi.org/10.1080/10967490902865107

Van den Hoek, R. E., M. Brugnach, and A. Y. Hoekstra. 2012. Shifting to ecological engineering in flood management: introducing new uncertainties in the development of a Building with Nature pilot project. Environmental Science \& Policy 22:85-99. http://dx.doi.org/10.1016/j.envsci.2012.05.003

Van Koningsveld, M., J. P. M. Mulder, M. J. F. Stive, L. van der Valk, and A. W. van der Weck. 2008. Living with sea-level rise and climate change: a case study of the Netherlands. Journal of Coastal Research 24(2):367-379. http://dx.doi.org/10.2112/07A-0010.1

Vranken, M., O. Oenema, and J. Mulder. 1990. Effects of tide range alterations on salt marsh sediments in the Eastern Scheldt, S.W. Netherlands. Hydrobiologia 195:13-20. http://dx.doi. org/10.1007/BF00026810

Weick, K. 1995. Sensemaking in organizations. Sage, Thousand Oaks, California, USA. 
Appendix. Example of the method used

In this Appendix, we provide an example of the methods used in our paper. We extensively discuss how we built Table 5, concerning the ambiguity about the effects of the Safety Buffer nourishment on oyster beds. Regarding this particular ambiguity, the project team and the representatives of the oyster sector have different frames. For both actors, we show how we identified their frame regarding the Safety Buffer's effects and the actor attributes associated to this frame, by assessing the research questions posed in Table 1 using our research material (such as transcripts of interviews and meetings we attended, project documents and even a media publication). Table 1 can be found in the Methods section of the paper. Table 5 is presented in the Case study II: Safety Buffer Oyster Dam section.

\title{
Project team frame and attributes
}

The project team's frame regarding the Safety Buffer is that it is an innovative and socially acceptable pilot project, that is vital to learn about possibilities for future dike maintenance and dealing with the effects of the Sand Hunger. The project team consists of employees of the governmental and non-governmental institutions that proposed the Safety Buffer initiative. Such institutions initiate and support an initiative if they are convinced of its innovative potential and the opportunities it can provide. They would not initiate or support an initiative if it is socially unacceptable, e.g. because there is a considerable risk that stakeholders will be harmed. More specifically, the project team will not execute the project if they frame the Safety Buffer as an unacceptable initiative with regard to the oyster sector. As a representative of the municipality were the oyster beds are located remarked:

\footnotetext{
"We cannot imagine that [the project team] will dump a pile of sand there without looking at the consequences. That is not how Rijkswaterstaat works... Rijkswaterstaat [observed] that [problem] with the oyster sector. So they immediately indicated: well, we will perform the [sand] mining and nourishment very carefully. We will monitor very well. We will [monitor] if there is [damage] or no damage. So I got the feeling: they are really on top of it and will not [perform the project] just like that. No, it is really a process that has been [done] carefully from the beginning until the end."
}

During the meeting of the Safety Buffer knowledge team we attended - several project team members are also part of this team - the following statements illustrate how those responsible for the Safety Buffer project frame the initiative and the positive intentions they have towards the stakeholders:

\begin{abstract}
"[The Safety Buffer] is viewed as a unique project to yield knowledge about the Sand Hunger... We want to learn from this... How can I slow down [or] reduce the Sand Hunger with this [concept]." "The fact that you create a Safety Buffer at all, with the idea: it extends the maintenance period of such a dike... [By doing this project, we can] provide insight about that and make that reasoning transparent. And that is a very complicated [issue]... What does [the Safety Buffer concept] mean for [flood] safety?" "If we want to enter that [participatory] process with the stakeholders, then we need to be open and say: [stakeholders], how do we [feel] and what puts [you] into trouble? Or are their opportunities? How are we going to make something out of [this project] that makes everyone stronger?"
\end{abstract}

Following Table 1, we identified the main interest of the project team by answering the research question 'what are the main ambitions or goals of the actor?'. For the project team, 
we identified that their main interest is to learn about how to improve dike maintenance, while simultaneously aiming to improve the Eastern Scheldt estuary's natural, recreation and user quality. We identified this actor attribute from our interviews with those associated with the project team. For instance, the following was stated:

\begin{abstract}
"Which interests play a role? It just started, very basically, with [dike] strengthening... [Additionally], we would, by [nourishing] sand, do something about the Sand Hunger, restore the natural value to what it was 20 years ago... And then additionally the combination with some recreation and of course [some benefits for] the mussel and oyster sector." "An important reason why the project team eventually did not choose the first design we had, was because we wanted to learn from [the project]... And then we entered in discussion: yes, but how do we learn the most?"
\end{abstract}

Following Table 1, we identified the main values of the project team by answering the research questions 'which moral principles does the actor hold as important regarding the topic? which criteria or boundary conditions are used to evaluate the topic?'. For the project team, we identified that an important value is their social responsibility for the well-being of the Eastern Scheldt estuary. Interviewees said the following about this:

"The higher goal. The higher goal: the Eastern Scheldt has to stay well. And we all want to get money out of it and enjoy it. But how do we do that?" "We very much want that [the Safety Buffer] is a step in working towards a sustainable Eastern Scheldt" "Whoever wants to join should pull up a chair, in order to jointly attempt to develop the Eastern Scheldt sustainably.”

An important value of the project team with regard to stakeholders in general - and hence with regard to the oyster sector in specific - is that they view it as their responsibility not to harm the interests of stakeholders. This value was an explicit boundary condition for the design process. During a sounding board meeting on 18 November 2011, this was explicitly communicated by a project team representative to all stakeholders present. In the minutes of that meeting, the following is reported:

During the development of the final design, the following 4 design criteria will be applied: (1) the users [i.e., stakeholders] and functions must not be damaged by either the dredging [i.e., sand mining] or sand nourishment... (3) if there is unexpected damage - in contradiction to the scientific insights - then this will be compensated according to the common claim settlements.

Following Table 1, we identified the beliefs of the project team by answering the research question "which propositions or premises does the actor hold to be true regarding the topic (even if there is no or contradictory evidence)?'. Regarding the ambiguity about the effects of the Safety Buffer on the oyster beds, the project team clearly believes that the project will not have adverse effects on shellfish beds. During the sounding board meeting of 20 April 2012, which we attended, this belief was explicitly communicated to those present. In the minutes of the meeting, it is reported that the risk of damage for the mussel and oyster sector is minor for the preferred design alternative. During the interviews, project team members avoided direct statements concerning the oyster sector, but the following quote - although an implicit statement - clearly supports the belief we identified:

"In [the oyster sector's] way of thinking, it was about damage and so forth. Because that was their major concern: 'there comes the sand'. Because [the Safety Buffer] was in the center [of the estuary] and of course, there are all those oysters. But those are very far away [from the Safety Buffer]." 
Furthermore, the propositions that the project will not have adverse effects on shellfish beds was based on the belief that the judgments of experts involved in the project yield trustworthy predictions. We observed that no modeling studies were present among the project documentation, which points at the key role of experts in predicting the effects of the project. An interviewee remarked the following on this:

"[The design process was done] particularly with expert knowledge. And thus hardly based on data and that sort of things or models... I think that [any of the designs] will not really give any trouble for those [oyster] beds nearby, as long as some [precautions] are taken. And that has to do with the construction... [more than] with the spreading of the sand after [construction]."

Following Table 1, we identified the background of the project team by answering the research questions 'which expertise, education or specific knowledge does the actor have regarding the topic? is the actor an expert or a layman regarding the topic?'. Several members of the project team - some of which we have interviewed - are an employee of Rijkswaterstaat, the state water authority of the Netherlands. Obviously, these are individuals with extensive expertise and knowledge regarding water management issues in general and sand nourishments in specific. Furthermore, an interviewed project team member - who is not an employee of Rijkswaterstaat - stated the following:

"[Regarding] the expertise there is [at Rijkswaterstaat] in Middelburg and their commitment...[Currently], it is more about contract management...the advanced engineering... Yes, Rijkswaterstaat is just immensely experienced with that... My admiration and respect for Rijkswaterstaat has grown [due to this project]."

Following Table 1, we identified the experiences of the project team by answering the research question 'from which (personal) historical situations does the actor draw to interpret the topic?'. Regarding these experiences, the project team regularly points at the positive results of other nourishment pilots in recent years to strengthen their argument and to justify the development of the Safety Buffer. For instance, during the interviews, the following was stated:

"Then, we were busy with the Sand Hunger Survey in the Eastern Scheldt. And we were looking for the next pilots or experiments after the Galgeplaat [and the] Schelphoek [nourishment] pilot. Because those were all well on track. But now [we were looking for] something bigger... Galgeplaat went well." "[The Safety Buffer provides the opportunity] to extend the experience that we have gained with sand nourishments in the Eastern Scheldt."

Additionally, the success of previous pilots is often referred to in project documents, such as the so-called Execution Plan Safety Buffer Oyster Dam. This plan includes statements about the Galgeplaat nourishment, such as:

The results of this small-scale experiment are promising... However, in order to work on the strengthening of the tidal flats on a larger scale, [both] more knowledge and pilot projects on a larger scale are required... This Safety Buffer Oyster Dam project can contribute regarding this knowledge requirement.

Following Table 1, we identified the actor position of the project team by answering the research question 'what is the societal or political position of the actor regarding the topic compared to other relevant actors, in terms of power or influence?'. We uncovered that the 
actor position of the project team regarding the specific ambiguity we are addressing in this Appendix is ambivalent. Although the project team is a powerful actor supported by the government, they claim to be unable to overrule the economically vital oyster sector. Moreover, this claim was supported by several stakeholders we interviewed. A selection of quotes from our interview material illustrates this:

"Could you potentially be able to overrule the shellfish sector?... That will not work. You cannot just overrule the shellfish sector. Just to be clear, we don't even want that." (interviewed project team actors) "If you have that entire sector against you, they can just block such a plan. They have that power." "If the entire oyster sector becomes obstructive, [the project] will get into trouble." (interviewed stakeholders)

\section{Oyster sector frame and attributes}

The oyster sector frame regarding the Safety Buffer project is that it is an unacceptable initiative due to its potential adverse impacts on the oyster sector. Nevertheless, the sector does acknowledge that the quality of the estuary is degrading due to the Sand Hunger. We identified this frame based on the following statements of a representative of the oyster sector we interviewed:

\footnotetext{
"We, [the] Dutch Oyster Association, acknowledge that there is a problem in that Eastern Scheldt, thus that there is Sand Hunger... We were absolutely not amused [about the project]; that is obvious... We do not pay for it, we didn't ask for it, we will never ask for it at that spot. We are in fact against [the Safety Buffer] at that spot. Because we prefer not to see it [constructed]. Because we do not need it... Why do you have to do it exactly where our [oyster]beds are?... There always is a certain risk. So I am convinced that you can never give $100 \%$ watertight guarantees for the future."
}

Following Table 1, we identified the main interest of the oyster sector by answering the research question 'what are the main ambitions or goals of the actor?'. The oyster sector is represented, both in the Safety Buffer project and in general, by the Dutch Oyster Association (in Dutch: Nederlandse Oestervereniging). This organization consists of nearly all commercial oyster producers. As the main goal of a common commercial business is to be as profitable as possible within reasonable and ethical boundaries, we argue that it is reasonable to assume that the main interest driving the oyster sector is maximizing their profit. Consequently, the specific concern of the oyster sector regarding the Safety Buffer project is that it could endanger their profitability. As the interviewee stated:

"My interest is that there is no damage of course... What if those oyster die?... Then it is a natural disaster, they'll say. Oyster producers: gone!... If it goes wrong here, then you have a significant [financial] loss."

Following Table 1, we identified the main values of the oyster sector by answering the research questions 'which moral principles does the actor hold as important regarding the topic? which criteria or boundary conditions are used to evaluate the topic?'. We identified that, despite their focus on their own business, both the oyster and mussel sector feel a social responsibility for the well-being of the Eastern Scheldt estuary in which they cultivate their shellfish. Several interviewees commented on this. For instance, the following was said:

"We, [the] Dutch Oyster Association, acknowledge that there is a problem in that Eastern Scheldt, thus that there is Sand Hunger" "On the one hand, [the shellfish sector] constantly says: we commit ourselves, we want to contribute to it... But on the other hand, you have to realize that their interest is, of course, rather 
minor. It is a societal responsibility they feel which they bear there. So that is an interesting position of the [shellfish] sector. They have no obligation, it maybe isn't even in their own interest and nevertheless, they still do it... Yes, less tidal flats theoretically [means] more mussel cultivation beds or oyster cultivation beds. But they are not into it like that. Fortunately!" "We were able to experience the blessings of the Delta Works, in the sense that [those made it possible that] the shellfish culture in Zeeland [still] exists. But [now] we are confronted with the side effects. And that is, among others, the Sand Hunger... So we do not want to turn our back to the societal reality of what is going on and that that is experienced as a loss from [a] natural point of view."

Following Table 1, we identified the beliefs of the oyster sector by answering the research question 'which propositions or premises does the actor hold to be true regarding the topic (even if there is no or contradictory evidence)?'. Regarding the specific ambiguity discussed in this Appendix, we identified one essential belief: the Safety Buffer will almost certainly have negative effects on the oyster beds. The main representative of the oyster sector sharply communicated this belief in an interview with the regional newspaper in May 2011. It was actually due to this interview that the ambiguity between the project team and the oyster sector surfaced:

If this [nourishment] takes place, that means the deathblow for the [oyster] sector.

Furthermore, the oyster sector representatives expressed similar concerns in a letter sent to the members of the Provincial authority in August 2011:

The oyster sector is very worried about the [proposed] nourishment at the Oyster Dam... In case of an excess of sand transport, [the oysters] will be covered...and will suffocate. With major anxiety we await the execution of the project plan.

During the interviews, the bottom line of the concerns was expressed as follows:

"We are very concerned that, (a) during the sand mining... that sand will enter the oysters, causing the oysters to die... and $(b)$ [similarly], at the moment that the sand nourishment has taken place at the Oyster Dam."

Following Table 1, we identified the background of the oyster sector by answering the research questions "which expertise, education or specific knowledge does the actor have regarding the topic? is the actor an expert or a layman regarding the topic?'. This attribute was partly derived by using common sense. Obviously, both the representatives of the oyster sector - i.e., the Dutch Oyster Association - and the commercial oyster companies are not experts regarding water management or sand nourishments, as this is not their profession. Regarding the background of the oyster sector, our interviewee touched upon this while describing the reason of their involvement in the project:

"There are two production sites [in Zeeland]: Lake Grevelingen and the Eastern Scheldt. In the Eastern Scheldt, the oyster beds are located in the immediate vicinity of the Oyster Dam... Therefore, we are a stakeholder [regarding the Safety Buffer]."

Following Table 1, we identified the experiences of the oyster sector by answering the research question 'from which (personal) historical situations does the actor draw to interpret 
the topic?'. The oyster sector aimed to strengthen their argument by pointing at the negative side effects on a mussel bed due to an earlier nourishment pilot. As our interviewee stated:

"Look, the first pilot, so that was on a tidal flat at the Schelphoek. [A pilot] regarding that Sand Hunger. Well, [at the Schelphoek], there is some damage at a mussel bed. But that is [just] an incidental damage. However, if it goes wrong here [at the Safety Buffer and the oysters are harmed], then you have a significant [financial] loss... Yes, so therefore we proposed to raise a damage fund."

Following Table 1, we identified the actor position of the oyster sector by answering the research question "what is the societal or political position of the actor regarding the topic compared to other relevant actors, in terms of power or influence?'. Similar to the project team, the actor position of the oyster sector is ambivalent. The oyster sector has no formal power to prevent project implementation, as they do not have the authority to take decisions. Nevertheless, because the oyster sector is an economically vital actor, this suggests they have a powerful position (as discussed above regarding the actor position of the project team). For instance, an interviewed project member stated:

"The oyster sector is really very important for Zeeland... There is big money in that [sector]. And there are major interests [attached] to that."

However, during the interview, the oyster sector representative claimed that his sector does not have a powerful actor position and cannot influence the development of the Safety Buffer:

"We, [the oyster sector], are of course a very important party in this whole business... Well, the people I represent, they are [against] that sand nourishment... [However], it is fighting windmills... Opposing Rijkswaterstaat and the Province, that is too much for me and my 36 [Dutch Oyster Association] members." 